\title{
SOLITARY THYROID NODULE- INCIDENCE AND HISTOPATHOLOGY- A 3-YEAR STUDY
}

\author{
Sheela Varghese1, Letha Vilasiniamma²
}

${ }_{1}^{1}$ Assistant Professor, Department of Pathology, Government Medical College, Kottayam.

${ }^{2}$ Additional Professor, Department of Pathology, Government Medical College, Kottayam.

ABSTRACT

\section{BACKGROUND}

Thyroid diseases are common all over the world. The finding of a solitary thyroid nodule (STN) on clinical examination of the thyroid is a common experience by the surgeons. A variety of benign and malignant lesions can present as a solitary nodule. Thyroid cancer is the most common malignancy arising in the endocrine system.

This study is undertaken to evaluate the various thyroid lesions, which can present clinically as solitary nodule. There is a high risk of malignancy in STN than in multiple nodules. STN evaluation, diagnosis and management should be done in a systematic manner.

Study Design- Descriptive study.

\section{MATERIALS AND METHODS}

This study was a descriptive study. The evaluation of the thyroid lesions presented as solitary nodule were done at the Department of Pathology, Govt. Medical College, Kottayam. Data regarding thyroidectomy specimens were obtained from the registers and requisition forms received in the department. Formalin fixed paraffin embedded tissue sections were used for Haematoxylin and Eosin ( $\mathrm{H}$ and $\mathrm{E}$ ) staining. $\mathrm{H}$ and $\mathrm{E}$ stained sections were evaluated histopathologically using light microscope. Data were recorded accordingly.

\section{RESULTS}

Among the 32,009 biopsy specimens received in the department during the 3-year period, 1054 were thyroidectomies; $22 \%$ of the thyroidectomy specimens were solitary nodules. Maximum numbers of solitary nodules were seen in the $4^{\text {th }}$ decade. Female constituted $78.1 \%$ of cases and the most common malignant lesion among the STN were papillary carcinomas.

\section{CONCLUSION}

The evaluation of a solitary nodule is a challenging area for the clinicians and pathologist. Varied lesions can present as thyroid nodule. Meticulous sampling and evaluation is needed for accurate diagnosis. The prognosis in general depends on the exact histopathological diagnosis and followup of all cases of thyroid diseases, especially solitary nodules.

\section{KEYWORDS}

Solitary Nodule, Thyroid, Carcinoma.

HOW TO CITE THIS ARTICLE: Varghese S, Vilasiniamma L. Solitary thyroid nodule- incidence and histopathology- a 3-year study. J. Evolution Med. Dent. Sci. 2017;6(88):6153-6156, DOI: 10.14260/jemds/2017/1336

\section{BACKGROUND}

Thyroid diseases constitute one of the most common diseases of the endocrine glands. According to National Cancer Registry Programme by Indian Council of Medical Research (ICMR), a data of cancer patients in six cities of India (Mumbai, Delhi, Thiruvananthapuram, Dibrugarh, Chandigarh and Chennai) during the period of 1984 - 1993 included 300,000 patients. Among these, 5614 cases were thyroid cancers. Among these centres, Trivandrum was the 1 st among the relative frequency of thyroid cancers. The nationwide relative frequency of thyroid cancer was $0.1 \%$ $0.2 \%$ among all other cancers. ${ }^{1}$ Various other studies showed around $1 \%$ incidence of thyroid malignancies among all malignancies. Discrete thyroid nodules are common and are present in $3 \%-4 \%$ of adult population in UK and USA. A discrete swelling in an otherwise

'Financial or Other Competing Interest': None.

Submission 26-09-2017, Peer Review 25-10-2017,

Acceptance 31-10-2017, Published 06-11-2017.

Corresponding Author:

Dr. Letha Vilasiniamma,

Additional Professor,

Department of Pathology,

Government Medical College, Kottayam.

E-mail:drlethav@gmail.com

DOI: $10.14260 /$ jemds $/ 2017 / 1336$ non-palpable gland is called as solitary nodule. The importance of discrete swelling lies in the risk of neoplasia when compared to other thyroid swellings. The annual incidence of thyroid neoplasia is about 3.7 per 100,000 population and the female-to-male ratio being 3: 1. [Bailey and Love's Short Practice of Surgery, 24th edition].

Most of the malignant lesions were present as a solitary nodule. It is worth to evaluate the incidence and the histopathological pattern of thyroid lesions presenting as solitary nodule.

\section{Objectives}

1. To assess the incidence, age and sex distributions of thyroid lesions presenting clinically as solitary nodule.

2. To establish the different histopathological entities, which can present as solitary nodules.

\section{MATERIALS AND METHODS}

This study was a descriptive study. Data regarding the thyroidectomy specimens has been collected from the registers and request forms in the department.

In the present study incidence, age and sex distribution of thyroid lesions presented as solitary nodules (both clinically and on gross examination) were assessed.

The histopathological evaluation has been done from the haematoxylin and eosin stained sections. 
From the gross specimens received along with the request form, full description of the gross specimen has been done and specimens where only solitary nodules seen grossly were selected for the study. Solitary nodules were seen in the lobes/ isthmus. Formalin fixed paraffin embedded tissue of the representative areas were selected for microtomy; $5 \mu \mathrm{m}$ sections were selected for Haematoxylin and Eosin staining. Lesions where there were capsules, full circumference of the lesion were included for the histopathological examination to assess capsular or vascular invasion, especially in suspected cases of follicular adenomas and carcinomas. Statistical analyses have been done with regards to the percentage of thyroidectomy specimen among the total specimen received in the study period. The percentage of solitary nodules in relation to the total thyroidectomy specimens, the age and sex wise distribution of solitary nodules, histopathological lesions in different age and sex groups.

\section{RESULTS}

In the present study, evaluation of the incidence of thyroid lesions which has been presented as solitary nodule were done from the thyroidectomy specimens received in the Department of Pathology during the 3-year study period.

A variety of benign and malignant lesions were presented as solitary nodules. Benign lesions observed were follicular adenoma, colloid nodule, thyroglossal cyst, Hurthle-cell adenoma and hyperplastic nodule. The various malignant lesions were papillary carcinoma, medullary carcinoma (Figure 1, 2), follicular carcinoma and anaplastic carcinoma. The commonest malignant lesion was papillary carcinoma.

The total number of Biopsy specimens received in the department during the study period was 32,009 and the thyroidectomy specimens were 1054 (3.3\% of all biopsy specimens). Among the thyroidectomy specimens, solitary nodules constituted $22.1 \%$ of cases. The youngest patient in this series was 2 years old male child and the oldest patient was 70 years old female. Females constituted $78.1 \%$ of cases and males $29.9 \%$ of cases. Male: Female ratio being 1: 5 . A variety of benign and malignant lesions presented as solitary nodule. Follicular adenomas constituted the maximum number of cases. The youngest patient presented with follicular adenoma was an 18 years old male and the oldest one was 68 years old male. The maximum numbers of solitary nodules were seen in the $4^{\text {th }}$ decade. The most common malignant lesion was papillary carcinoma. The variants of which included conventional papillary carcinoma, follicular variant and tall cell variant. Conventional papillary carcinoma was maximum in the $3^{\text {rd }}$ and $4^{\text {th }}$ decades. Follicular variant was seen from $3^{\text {rd }}$ to $5^{\text {th }}$ decade and tall cell variant in $7^{\text {th }}$ decade.

The distribution and percentage of different lesions presented as solitary nodule is depicted in Table I. Among the 233 solitary nodules, 194 were benign (83.3\%) and 39 were malignant (16.7\%). Among the malignant lesions $66.6 \%$ were papillary carcinomas, $23 \%$ were follicular carcinomas, $5.1 \%$ were medullary carcinomas, 2.5 were Hurthle cell carcinomas and $2.5 \%$ were anaplastic carcinomas. Differentiated carcinomas were seen in both younger and older age groups. Anaplastic carcinoma occurred in the $8^{\text {th }}$ decade. The incidence of differentiated carcinomas in solitary nodules was evaluated by few authors given in Table II.
The histological features of conventional papillary carcinoma showed typical architectural features and nuclear features, i.e. papillary structures lined by columnar cells showing nuclear crowding overlapping, growing, clearing and intranuclear pseudo inclusions. Follicular variant showed follicles with typical nuclear features of papillary carcinomas. Tall cell variant showed papillae lined by cells with height 3 times the width (Figure III) and with typical nuclear features of papillary carcinoma.

Medullary carcinomas showed predominantly spindle cell morphology with amyloid deposition within the tumour (Figure IV). Amyloid demonstrated by salmon pink colour on Congo red stain and apple green birefringence on polarised light. Anaplastic carcinoma showed sheets of pleomorphic tumour cells without identifiable differentiation, increased mitosis and necrosis (Figure V). The percentage of malignancy observed in solitary nodules by different authors was depicted in Table III. The predominant age range, mean age and male: female ratio of solitary nodules stained by different authors were depicted in Table IV.

\begin{tabular}{|c|c|c|}
\hline Lesion & No. of Cases & Percentage \\
\hline Follicular Adenoma & 131 & 56.2 \\
\hline Colloid Nodule & 37 & 15.9 \\
\hline Toxic Nodule & 1 & 0.43 \\
\hline Thyroglossal Cyst & 16 & 6.8 \\
\hline Hurthle Cell Adenoma & 9 & 3.8 \\
\hline Papillary Carcinoma & 26 & 11.2 \\
\hline Follicular Carcinoma & 9 & 3.8 \\
\hline Medullary Carcinoma & 2 & 0.85 \\
\hline Hurthle Cell Carcinoma & 1 & 0.43 \\
\hline Anaplastic Carcinoma & 1 & 0.43 \\
\hline \multicolumn{3}{|c|}{$\begin{array}{c}\text { Table I. Distribution and Percentage of different Lesions } \\
\text { presented as Solitary Nodule }\end{array}$} \\
\hline
\end{tabular}

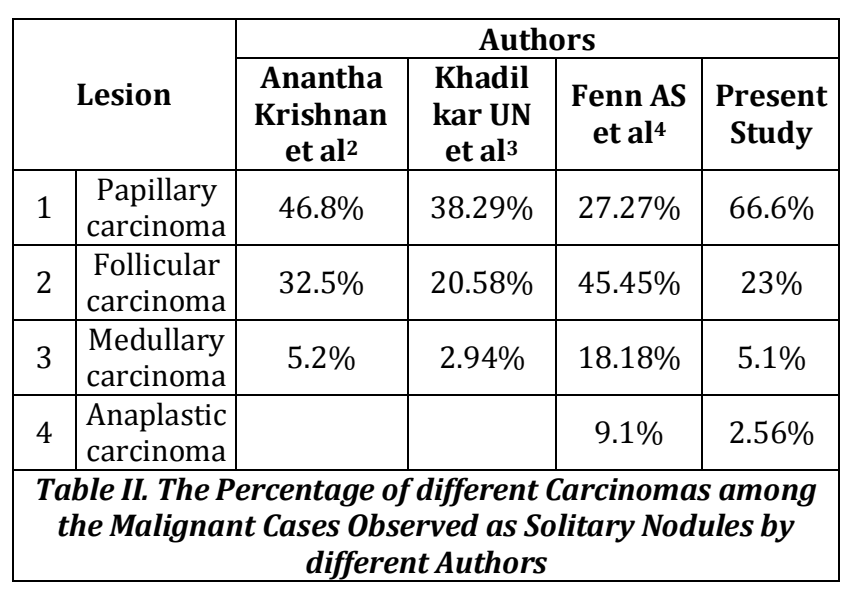

\begin{tabular}{|c|c|c|}
\hline Sl. No. & Author & \% of Malignancy \\
\hline 1 & C Leigh et al 5 & 20.9 \\
\hline 2 & A K Sarda et al 6 & 10.8 \\
\hline 3 & Mazafferi et al ${ }^{7}$ & $11-12$ \\
\hline 4 & Judy Jin et al ${ }^{8}$ & 15 \\
\hline 5 & Md. Abdul Hosain et al ${ }^{9}$ & 12.3 \\
\hline 6 & Naz Akhtar et al ${ }^{10}$ & 15.3 \\
\hline 7 & Ramesh Babu et al 11 & 10.8 \\
\hline 8 & Nagori LF et al ${ }^{12}$ & 11 \\
\hline 9 & Ananthakrishnan et $\mathrm{al}^{2}$ & 15.3 \\
\hline 10 & Khadilkar UN et al ${ }^{3}$ & 21 \\
\hline 11 & Balaji Dharman et al13 & 8 \\
\hline 12 & Present study & 16.7 \\
\hline \multicolumn{3}{|c|}{$\begin{array}{c}\text { Table III. Incidence of Malignancy in Solitary Thyroid } \\
\text { Nodule-Comparison with Other Studies }\end{array}$} \\
\hline
\end{tabular}




\begin{tabular}{|c|c|c|c|c|}
\hline $\begin{array}{c}\text { Sl. } \\
\text { No. }\end{array}$ & Author & $\begin{array}{c}\text { Age } \\
\text { Range }\end{array}$ & $\begin{array}{c}\text { Mean } \\
\text { Age }\end{array}$ & $\begin{array}{c}\text { Male: } \\
\text { Female }\end{array}$ \\
\hline 1 & ${\text { Singh P et al }{ }^{14}}^{1}$ & $12-80$ & 47 & $1: 4.7$ \\
\hline 2 & El Hag IA et al $^{15}$ & $9-90$ & 36 & $1: 5.4$ \\
\hline 3 & Sangalli G et al $16^{16}$ & $6-91$ & 47 & $1: 4.2$ \\
\hline 4 & Ramesh Babu et al $^{11}$ & - & - & $1: 8$ \\
\hline 5 & Handa U et al $^{17}$ & $5-80$ & 37.7 & $1: 6.4$ \\
\hline 6 & Mandal S et al $^{18}$ & $15-71$ & - & $1: 5$ \\
\hline 7 & Balaji Dhanaram et al $^{14}$ & - & - & $1: 5.6$ \\
\hline 8 & S Anitha et al ${ }^{19}$ & - & 35.7 & $1: 6.7$ \\
\hline 9 & Present study & $2-70$ & 38 & $1: 5$ \\
\hline $\begin{array}{c}\text { Table IV. Age Range, Mean Age and Male: Female Ratio of } \\
\text { Patients presented with Solitary Nodule } \\
\text { in different Studies }\end{array}$ \\
\hline
\end{tabular}

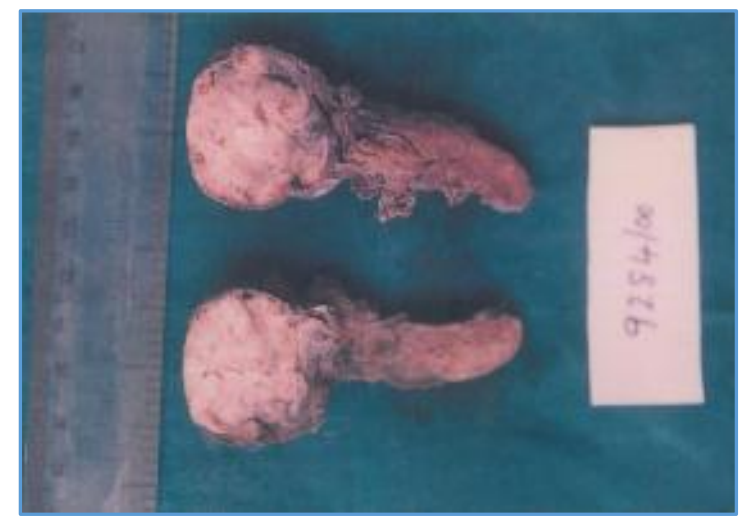

Figure I. Medullary Carcinoma as a Solitary Nodule at the Upper Pole of Thyroid (Cut Section)

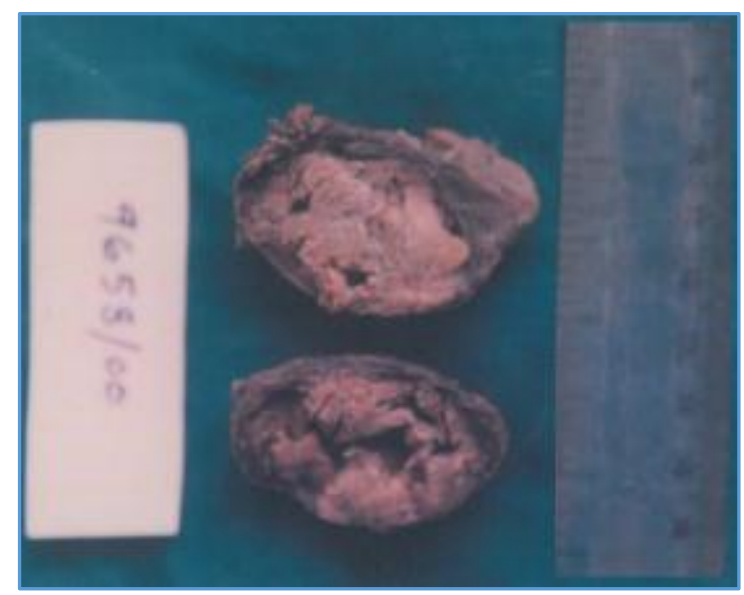

Figure II. Papillary Carcinoma as a Solitary Nodule (Cut Section)

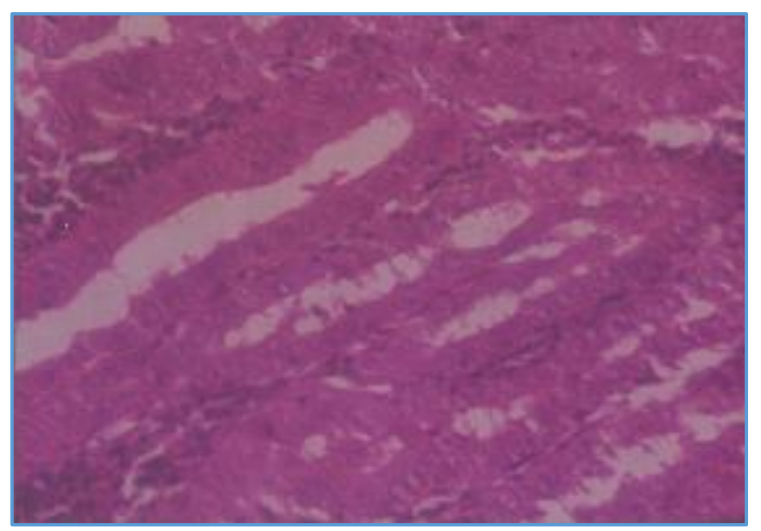

Figure III. Papillary Carcinoma, Tall Cell Variant. H and E [400x]

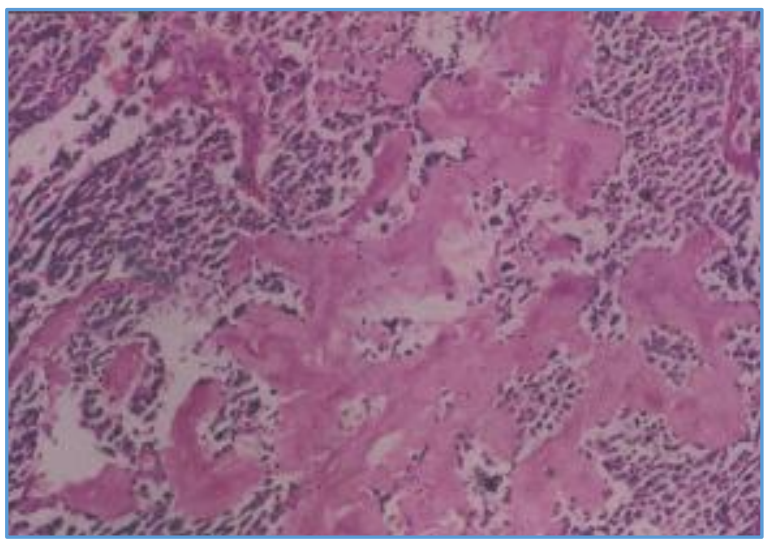

Figure IV. Medullary Carcinoma showing Amyloid. Hand $E$ [400x]

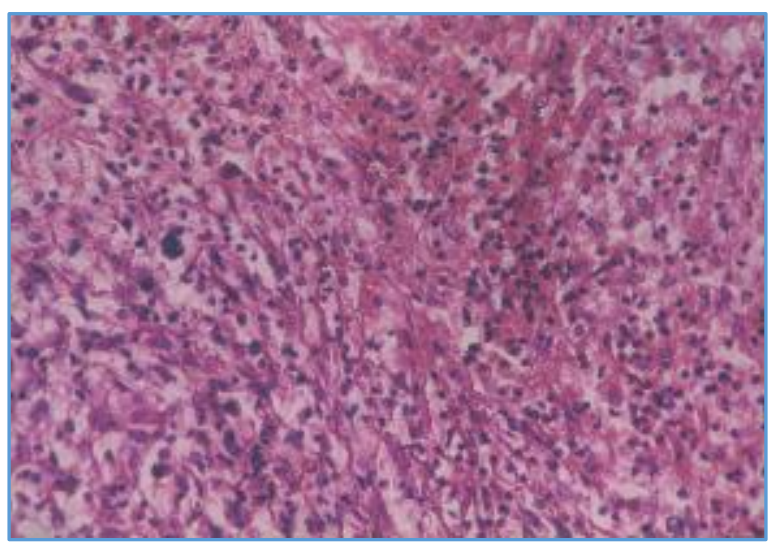

Figure V. Anaplastic Carcinoma showing Mitosis. $H$ and $E$ [400X]

\section{DISCUSSION}

In the present study the incidence of thyroid lesions presented as solitary nodule, age and sex distribution and histological patterns were analysed. Solitary nodules constituted $3.3 \%$ of thyroidectomy specimens in the study period. A series by Anitha et al, solitary nodule constituted $1.67 \%$ of all surgical specimens. ${ }^{19}$

In the present study, the benign lesions presented as solitary nodules were follicular adenoma, colloid nodule, thyroglossal cyst, Hurthle cell adenoma and toxic nodule. The malignant lesions were papillary carcinoma, follicular carcinoma, medullary carcinoma, Hurthle cell carcinoma and anaplastic carcinoma. Among the benign lesions, follicular adenomas constituted the major lesions (56.2\%). According to Das $\mathrm{AB}$ et al 20 the lesions presented as solitary nodule included colloid nodule, thyroid cysts, follicular adenoma, adenoma with cystic change, sub-acute thyroiditis and papillary carcinoma. Among the benign lesions the commonest one was colloid nodule, which constituted $41 \%$. A series studied by Khadilkar et $\mathrm{al}^{3}$ also, the commonest benign lesion was colloid nodule (52\%).

A study conducted among 93 children $(<18$ yrs.) with solitary nodule 21 showed follicular adenomas as the commonest lesion (68.9\%) as in the present study.

A retrospective study by Keh et al $^{22}$ showed $75.4 \%$ of cases of neoplastic lesions among the 61 solitary nodules studied. Among these, 34.4\% were malignant lesions. Present study showed $16.7 \%$ of malignant lesions. The percentage of malignancy observed in different studies is shown in Table II. 
Among the malignant lesions papillary carcinoma was the commonest pathology in the present study, constituted by $66.7 \%$ of the malignant lesions.

A study conducted in 4187 patients with differentiated thyroid carcinomas showed papillary carcinoma as the commonest malignancy (88\%).23

The commonest age group where solitary nodules were observed in the present study was 30 - 39 years and the gender was female. Balaji Dharman et $\mathrm{al}^{13}$ observed the commonest age group as 20 - 30 years. The percentage of malignancy observed in solitary nodules by different authors is depicted in Table III.

The predominant age range, mean age and male: female ratio of solitary nodules studied by different authors is depicted in Table IV.

\section{CONCLUSION}

Solitary thyroid nodule is to be evaluated systematically by physical examination, imaging modalities, fine needle aspiration cytology and histopathology. A multitude of thyroid disorders can present as solitary nodule. The different lesions presented as solitary nodule in the present study include benign lesions like follicular adenoma, thyroglossal cyst, hyperplastic nodule, Hurthle adenoma and malignant lesions like papillary carcinoma, follicular carcinoma, Hurthle cell carcinoma, medullary carcinoma and anaplastic carcinoma. The youngest patient in this series was 2 years old male child and the oldest patient was a 70 years old female. The maximum numbers of solitary nodules were seen in the $4^{\text {th }}$ decade; $78.1 \%$ of cases were seen among females and $29.9 \%$ among males with a female: male ratio of $5: 1$. Children below 12 years constituted only $5.15 \%$ of cases. The incidence of malignant thyroid lesions presented as solitary nodule was $16.4 \%$.

\section{ACKNOWLEDGEMENT}

We express our sincere gratitude to the former professors of pathology, Dr. Agnessamma Jacob, Dr. Remadevi AV and the technicians of the Department of Pathology.

\section{REFERENCES}

[1] Unnikrishnan AG, Menon CV. Thyroid disorders in India: an epidemiological perspective. Indian J Endocrinol Metab 2011;15(Suppl 2):S78-81.

[2] Ananthakrishnan N, Rao KM, Narasimhan R, et al. The single thyroid nodule. A South Indian profile of 503 patients with reference to incidence of malignancy. Indian J Surg 1993;55(10):487-92.

[3] Khadilkar UN, Maji P. Histopathological study of solitary nodules of thyroid. Kathmandu Univ Med J 2008;6(24):486-90.

[4] Fenn AS, Krishnan KV, Devadatta J, et al. Solitary nodules of the thyroid gland. A review of 342 cases. Indian J Surg1980;42:175-77.

[5] Kendall LW, Condon RE. Prediction of malignancy in solitary thyroid nodules. The Lancet 1969;293(7605):1071-3.

[6] Sarda AK, Gupta A, Jain PK, et al. Management options for solitary thyroid nodules in an endemic goitrous area. Post Medical Journal 1997;73(863):560-4.
[7] Mazafferi G. The single thyroid nodule and carcinoma. Br J Surg 1974;61(12):943-4.

[8] Jin J, Wilhelm SM, McHenry CR. Incidental thyroid nodule: patterns of diagnosis and rate of malignancy. The American journal of malignancy. The American Journal of Surgery 2009;197(3):320-4.

[9] Hossain MA, Sarkar MZ, Dutta UK, et al. Frequency of malignancy in solitary thyroid nodule and multinodular goiter. Bangladesh J Otorhinolaryngology 2014;20(2):55-65.

[10] Majeedullahbuzdar N, Amjadkhan M. Frequency of malignancy in solitary thyroid nodule. PJMHS 2015;9:983.

[11] Babu R, Madhavishyamala. Malignant incidence in solitary nodule thyroid- a clinical study. IJAR 2015:5.

[12] Nagori LF, Algotar MJ. Solitary solid thyroid nodule. Indian J Surg 1992;54(2):75-8.

[13] Dhanaram B, Arunachalam J, Muthukumaraswamy B. A clinicopathological study of solitary nodule of thyroid. Int Surg J 2017;4(7):2288-90.

[14] Singh P, Chopra R, Calton N, et al. Diagnostic accuracy of fine needle aspiration cytology of thyroid lesions. Journal of Cytology 2000;17(3):135-9.

[15] EI Hag IA, Kollur SM, Chiedozi LC. The role of FNA in the initial management of thyroid lesions. 7 year experience in a district general hospital. Cytopathology 2003;14(3):126-30.

[16] Sangalli G, Serio G, Zampattic C, et al. Fine needle aspiration cytology of the thyroid: a comparison of 5469 cytological and final histological diagnoses. Cytopathology 2006;17(5):245-50.

[17] Handa U, Garg S, Mohan H, et al. Role of fine needle aspiration cytology in diagnosis and management of thyroid lesion: a study of 434 patients. J Cytology 2008;25(1):13-7.

[18] Mandal S, Barman D, Mukherjee A, et al. Fine needle aspiration cytology of thyroid nodules-evaluation of its role in diagnosis and management. J Indian Med Association 2011;109(4):258-61.

[19] Anitha S, Ravimohan TR. A study of incidence of malignancy in solitary nodule of thyroid. International Journal of Contemporary Medical Research 2016;3(4):993-5.

[20] Das AB, Alam MN, Hag SA, et al. Solitary thyroid nodule: a study of 100 cases. Bengladesh Med Res Coune Bull 1996;22(1):12-8.

[21] Hung W. Solitary thyroid nodules in 93 children and adolescents. Horm Res 1999;52:15-18.

[22] Keh SM, EI-Shunner SK, Palmer T, et al. Incidence of malignancy in solitary thyroid nodules. J Laryngol Otol 2015;129(7):677-81.

[23] Elisei R, Molinaro E, Agate L, et al. Are the clinical and pathological features of differentiated thyroid carcinoma really changed over the last 35 years? Study on 4187 patients from a single Italian institution to answer this question. J Clin Endocrinol Metab 2010;95(4):1516-27. 